\title{
The Austrian Bone Marrow Donor Registry: Providing Patients in Austria with Unrelated Donors for Transplant - a Worldwide Cooperation
}

\author{
Agathe Rosenmayr ${ }^{a, b} \quad$ Margit Pointner-Prager ${ }^{b} \quad$ Martina Winkler ${ }^{b} \quad$ Andrea Mitterschiffthaler $^{b}$ \\ Barbara Pelzmann $^{b}$ Ljiljana Bozic ${ }^{b}$ Sonja Pichler-Kurzweil ${ }^{b}$ Heinz Tüchler ${ }^{c}$ Ingrid Fae ${ }^{a}$ \\ Gottfried Fischer ${ }^{\mathrm{a}}$
}

a Department of Blood Group Serology, Medical University of Vienna,

${ }^{\mathrm{b}}$ Austrian Bone Marrow Donor Registry,

${ }^{\mathrm{c}}$ Department of Haematology, Hanusch Krankenhaus Vienna, Austria

\section{Keywords}

Unrelated Blood Stem Cell Donor · URD · MUD .

International Donor Search.

Haematopoietic Stem Cell Transplantation, HSCT

\section{Summary}

Background: The Austrian Bone Marrow Donor Registry is the central search coordinating unit in charge of national and international donor searches in Austria. Patients and Methods: Between 1988 and 2010, a worldwide search for an unrelated donor of blood stem cells (URD) was initiated for 2,166 Austrian patients with haematological disorders, 1,671 adults and 495 children, by the Austrian Bone Marrow Donor Registry. Results: An URD was identified for $78.3 \%$ of the patients between 2008 and 2010, for $76.7 \%$ of the patients between 2004 and 2007, for 71.3\% between 1996 and 2003 , but only for $53.4 \%$ of the patients in the initial period of 1988-1995. Thus, results of international donor searches improve over time. In contrast, search duration decreases steadily: Search times of successful searches decreased from about 8 months in the first period between 1988 and 1996 to 1.84 months in 2010 . Overall, 1,558 of the 2,166 patients $(71.9 \%)$ could be provided with a matching donor. However, not every patient provided with a URD was transplanted. Overall, only 1,141 of 2,166 patients $(52.7 \%)$ proceeded to transplant. Conclusion: Figures have significantly improved for the latest period of donor searches between 2008 and 2010. In this period, a donor could be found for $78.3 \%$, and $58.5 \%$ of the patients received a transplant.

\section{Schlüsselwörter}

Nichtverwandter Blutstammzellenspender - URD - MUD . Internationale Spendersuche

Hämatopoetische Stammzelltransplantation

\section{Zusammenfassung}

Hintergrund: Das Österreichische Stammzell-Register ist die zentrale Suchkoordinierungsstelle für die nationale und internationale Spendersuche in Österreich. Patienten und Methoden: Zwischen 1998 und 2010 wurde eine weltweite Suche für nichtverwandte Spender von Blutstammzellen (unrelated donors of blood stem cells; URD) für 2166 österreichische Patienten mit hämatologischen Erkrankungen (1671 Erwachsene, 495 Kinder) durch das Österreichische Stammzell-Register initiiert. Ergebnisse: Für 78,3\% der Patienten konnte zwischen 2008 und 2010 ein URD identifiziert werden; zwischen 1996 und 2003 gelang dies für 71,3\%. Während der Initiierungsphase zwischen 1988 und 1995 gelang dies hingegen nur 53,4\% der Patienten. Die Ergebnisse der internationalen Spendersuche verbesserten sich also über die Zeit. Gleichzeitig nahm die Suchdauer kontinuierlich ab: Die Suchzeiten für erfolgreiche Suchen sanken von 8 Monaten in der ersten Phase zwischen 1988 und 1996 auf 1,84 Monate im Jahr 2010. Insgesamt konnten 1558 von 2166 Patienten mit einem passenden Spender versorgt werden. Allerdings wurde nicht jeder Patient, für den ein URD gefunden wurde, tatsächlich transplantiert. Insgesamt 1141 von $2166(52,7 \%)$ Patienten erhielten eine Knochenmarkspende. Schlussfolgerung: Die Zahlen haben sich für die letzte Spendersuchperiode zwischen 2008 und 2010 deutlich verbessert. In diesem Zeitraum konnte für 78,3\% der Patienten ein URD gefunden werden und 58,5 der Patienten erhielten eine Transplantation.

\section{KARGER}

Fax +497614520714

Information@Karger.de

www.karger.com (c) 2011 S. Karger GmbH, Freiburg

Accessible online at:

www.karger.com/tmh

Dr. Agathe Rosenmayr

Department of Transfusion Medicine and Blood Group Serology

Medical University of Vienna

Währinger Gürtel 18-20, 1080 Vienna, Austria

Tel. +43 1 40400-5320, Fax -5321

agathe.rosenmayr@meduniwien.ac.at 


\section{Introduction}

Haematopoietic stem cell transplantation (HSCT) is the therapy of choice for many adults and children with malignant haematological diseases [1, 2]. A histocompatible family donor, most frequently a sibling, is available in only one third of the patients. In roughly two thirds of the patients, an unrelated haematopoietic stem cell donor must be found. Therefore, a search for a matched unrelated donor (URD) is necessary for the remaining two thirds of the patients. For the past 20 years, much effort has been put into the worldwide organization of searches for URDs [3,4]. Since comparable results in sibling and URD HSCT have been reported [5-9] during the last years, URD transplantation is a realistic chance for every patient in need. In Austria - a small country with only a limited number of URDs - a large majority of the donors must be obtained from the international donor pool. Several major international computer networks are available for the provision of URDs from all around the world [10,11]. About 15 millions international HSCT donors are registered [12] in a network of interconnected national hubs (National Haematopoietic Stem Cell Donor Registries), where the data of the national donors is stored electronically. Since January 1, 1988, the Austrian Bone Marrow Donor Registry has been the central search coordinating unit in charge of national and international donor searches in Austria. Patient and international donor search data from the last 23 years have been analyzed, showing that numbers of patients are increasing steadily as well as the results of the international donor searches for Austrian patients.

\section{Patients and Methods}

Characteristics of Patients for whom International Donor Searches Have Been Performed

2,166 Austrian patients for whom a URD search was started and completed between 1988 and 2010 were included in this analysis. A total of 378 patients with ongoing searches, where neither an official search stop order nor any other similar information have been received from the transplant centre, were excluded from the analysis. Of the 2,166 Austrian patients, 495 patients were children of up to 18 years, who were treated in paediatric departments, while 1,671 patients were adults. URD searches were always searches for both national and international donors. Table 1 shows the patient characteristics. The time frame under analysis has been subdivided into 4 periods: i) Search period I: January 1, 1988 to December 31, 1995 (8 years), 341 patients; ii) Search period II: January 1, 1996 to December 31, 2003 (8 years), 815 patients; iii) Search period III: January 1, 2004 to December 31, 2007 (4 years), 430 patients; Search period IV: January 1, 2008 to December 31, 2010 (3 years), 580 patients. The 4 periods have been chosen due to significant changes in search policies at the beginning of each period. From January 1, 1996 onwards, serological HLA class I typing for donor selection was replaced by intermediate resolution DNA typing for HLA class I. In addition, high resolution DNA typing for HLA class II has been used for final donor selection. The routine use of high resolution DNA typing of patients and donors for both HLA class I and II has been common practice since January 1, 2004. The routine use of new computer systems was started on January 1, 2008.

\section{Transplant Centres}

Patients came from the following Austrian transplant centres: Department of Internal Medicine I, Medical University of Vienna ( $\mathrm{n}=869)$; St. Anna Children's Hospital Vienna $(n=402)$; Department of Haematology, Medical University of Graz $(n=301)$; Department of Paediatrics and Adolescent Medicine, Division of Paediatric Haematology/Oncology, Medical University of Graz $(\mathrm{n}=88)$; 1st Department of Internal Medicine, Department of Oncology, Elisabethinen Hospital Linz ( $\mathrm{n}=122)$; Department of Haematology and Oncology, Medical University of Innsbruck $(\mathrm{n}=379)$; Department of Paediatric and Adolescent Haematology/ Oncology, Medical University of Innsbruck $(n=5)$.

\section{Patients' Nationality}

The large majority of the patients originated from Austria and neighbouring European countries (Germany, Switzerland, Italy, Luxembourg). These patients have been grouped into Northwest European or Middle European patients. As Austria has a large minority (6.7\% nationwide) of people from the former Yugoslavia and Eastern Europe, this minority is also represented among the patients. Another minority living in Austria originates from Turkey $(1.6 \%)$. Both minorities - the East and SouthEast European group as well as the Turkish group - came to Austria between 1950 and now [13]. Among our patients, 7.43\% were from East or South-East Europe, while 1.8\% were of Turkish origin. Since non-European patients from overseas are also sometimes treated in Austria, a group of non-European individuals can also be found among our patients $(3.0 \%)$. Exact numbers are detailed in table 1 .

\section{Procedures for Finding a National or International Donor}

The donor search process for a patient who does not have an HLA-identical sibling starts with an official order from the transplant centre accompanied by the high resolution HLA-typing of the patient and, if possible, of his parents and siblings. Typing of patients and their siblings is performed in the tissue typing laboratory of the transplant centre. After receipt of the formal order accompanied by the tissue type, the international donor search is immediately started in accordance with already published guidelines and procedures [14]. As soon as the official search order has been received, the Bone Marrow Donors Worldwide (BMDW) computer system is contacted in order to obtain an overview of available donors in the international donor pool. In the meantime, an international request goes out electronically via the European Marrow Donor Information System (EMDIS) computer system or other means to the international registries. Donors with the best matching tissue type in the highest resolution available are selected for confirmatory typing irrespective of their nationality. High resolution confirmatory HLA typing of patient and donor and the cross match test are performed in the tissue typing laboratory of the transplant centre. When the results of confirmatory typing, age, gender, and nationality of the donors are known, the attending physician of the transplant centre decides which donor will be selected and sets the date for transplant. Donor work-up is, again, organized by the Austrian Registry.

\section{Tissue Typing and Donor Selection Process}

During search period I, HLA typing involved serological HLA-A, -B, -C (HLA class I) typing as well as DNA-based low resolution typing of HLA-DRB1 and -DQB1 (HLA class II) alleles. Serological split typing of patient and donor for HLA class I determinants and the DNA-based low resolution typing for HLA class II determinants was the minimum requirement for selection of a donor for transplantation. During search period II, DNA typing for HLA class I at an intermediate level and DNA typing for HLA class II at high resolution level were mandatory. Typing was in part done by polymerase chain reaction sequence-specific oligonucleotide probe hybridization (PCR-SSO) and in part by nucleotide sequencing. During search periods III and IV, for both HLA-A, -B, -C and HLA-DRB1 and -DQB1 determinants, nucleotide sequencing of exons 1-3 for HLA class I and exon 2 for HLA class II alleles was 
Table 1. Characteristics of paediatric and adult patients during search activation periods I-IV

\begin{tabular}{|c|c|c|c|c|c|c|}
\hline & $\begin{array}{l}\text { Period I } \\
(1988-1995)\end{array}$ & $\begin{array}{l}\text { Period II } \\
(1996-2003)\end{array}$ & $\begin{array}{l}\text { Period III } \\
(2004-2007)\end{array}$ & $\begin{array}{l}\text { Period IV } \\
(2008-2010)\end{array}$ & $\mathrm{p}$ value ${ }^{\mathrm{a}}$ & Total \\
\hline \multicolumn{7}{|l|}{ Paediatric patients } \\
\hline Total, $\mathrm{n}$ & 124 & 207 & 58 & 106 & & 495 \\
\hline Annual patient accrual & 15.5 & 25.9 & 14.5 & 35.3 & & 21.5 \\
\hline Age median, years & 8.0 & 7.5 & 7.1 & 8.9 & n.s. & 8.0 \\
\hline Sex (male/female), $\mathrm{n}$ & $85 / 39$ & $125 / 82$ & $31 / 27$ & $66 / 40$ & n.s. & $307 / 188$ \\
\hline Male, \% & 68.5 & 60.4 & 53.4 & 62.3 & & 62.0 \\
\hline \multicolumn{7}{|l|}{ Region of origin, n (\%) } \\
\hline NW-M Europe & $105(84.7)$ & $162(78.3)$ & $39(67.3)$ & $77(72.6)$ & & $383(77.4)$ \\
\hline East and South-East Europe & $13(10.5)$ & $23(11.1)$ & $12(20.7)$ & $16(15.1)$ & & $64(12.9)$ \\
\hline Turkish & $3(2.4)$ & $10(4.8)$ & $2(3.4)$ & $5(4.7)$ & & $20(4.0)$ \\
\hline Non-European & $3(2.4)$ & $12(5.8)$ & $5(8.6)$ & $8(7.5)$ & & $28(5.7)$ \\
\hline NW-M Europe / non-NW-M Europe & 105/19 (18.0) & $162 / 45(27.7)$ & $39 / 19(48.7)$ & $77 / 29(37.7)$ & $<0.001$ & $383 / 112(29.2)$ \\
\hline Diagnosis, n (\%) & & & & & $<0.001$ & \\
\hline AML & $25(20.2)$ & $33(15.9)$ & $11(19.0)$ & $12(11.3)$ & & $81(16.4)$ \\
\hline ALL & $47(37.8)$ & $66(32.0)$ & $14(24.2)$ & $39(36.8)$ & & $166(33.5)$ \\
\hline MDS & $10(8.1)$ & $10(4.8)$ & $4(6.9)$ & $3(2.8)$ & & $27(5.5)$ \\
\hline CML & $15(12.1)$ & $18(8.7)$ & $1(1.7)$ & $2(1.9)$ & & $36(7.3)$ \\
\hline Lymphoma & $1(0.8)$ & $9(4.3)$ & $7(12.1)$ & $6(5.7)$ & & $23(4.6)$ \\
\hline SAA & $15(12.1)$ & $32(15.5)$ & $5(8.6)$ & $19(17.9)$ & & $71(14.3)$ \\
\hline Congenital diseases & $8(6.5)$ & $30(14.5)$ & $10(17.2)$ & $18(17.0)$ & & $66(13.3)$ \\
\hline Other & $3(2.4)$ & $9(4.3)$ & $6(10.3)$ & $7(6.6)$ & & $25(5.1)$ \\
\hline Transplant centre, n (\%) & & & & & n.s. & \\
\hline Vienna St. Anna Children's Hospital & $104(83.9)$ & $172(83.1)$ & $48(82.8)$ & $78(73.6)$ & & $402(81.2)$ \\
\hline Graz Children's Hospital & $20(16.1)$ & $35(16.9)$ & $10(17.2)$ & $23(21.7)$ & & $88(17.8)$ \\
\hline Innsbruck Children's Hospital & & & & $5(4.7)$ & & $5(1.9)$ \\
\hline \multicolumn{7}{|l|}{ Adult patients } \\
\hline Total, n & 217 & 608 & 372 & 474 & & 1,671 \\
\hline Annual patient accrual & 27.1 & 76 & 93 & 158 & & 72.6 \\
\hline Age median, years & 31.6 & 41.6 & 45.9 & 51.1 & $<0.000$ & 45.1 \\
\hline Sex (male/female), $n$ & $117 / 100$ & $347 / 261$ & $211 / 161$ & $282 / 192$ & 0.603 & $957 / 714$ \\
\hline Male, \% & 53.9 & 57.1 & 56.7 & 59.5 & & 57.3 \\
\hline \multicolumn{7}{|l|}{ Region of origin, n (\%) } \\
\hline NW-M Europe & $203(93.5)$ & $560(92.1)$ & $341(91.7)$ & $413(87.1)$ & & $1,517(90.8)$ \\
\hline East- and South-East Europe & $4(1.9)$ & $24(4.0)$ & $24(6.5)$ & $45(9.5)$ & & $97(5.8)$ \\
\hline Turkish & $3(1.4)$ & $13(2.1)$ & $2(0.5)$ & $1(0.2)$ & & $19(1.1)$ \\
\hline Non-European & $7(3.2)$ & $11(1.8)$ & $5(1.3)$ & $15(3.2)$ & & $38(2.3)$ \\
\hline NW-M Europe / non NW-M Europe & 203/14 (6.9) & $560 / 48(8.6)$ & $341 / 31(9.1)$ & $413 / 61(14.8)$ & $<0.01$ & $1,517 / 154(10.2)$ \\
\hline Diagnosis, n (\%) & & & & & $<0.000$ & \\
\hline AML & $70(32.3)$ & $213(35.0)$ & $183(49.3)$ & $213(44.9)$ & & $679(40.6)$ \\
\hline ALL & $37(17.0)$ & $116(19.1)$ & $60(16.1)$ & $67(14.1)$ & & $280(16.8)$ \\
\hline MDS & $3(1.4)$ & $49(8.1)$ & $31(8.3)$ & $49(10.3)$ & & $132(7.9)$ \\
\hline CML & $79(36.4)$ & $98(16.1)$ & $25(6.7)$ & $25(5.3)$ & & $227(13.6)$ \\
\hline Lymphoma & $6(2.8)$ & $81(13.3)$ & $55(14.8)$ & $74(15.6)$ & & $216(12.9)$ \\
\hline SAA & $14(6.4)$ & $17(2.8)$ & $5(1.3)$ & $18(3.8)$ & & $54(3.2)$ \\
\hline Congenital diseases & $3(1.4)$ & $4(0.7)$ & $3(0.8)$ & $0(0.0)$ & & $10(0.6)$ \\
\hline Other diseases & $5(2.3)$ & $30(4.9)$ & $10(2.7)$ & $28(5.9)$ & & $73(4.4)$ \\
\hline Transplant centre, n (\%) & & & & & $<0.000$ & \\
\hline Vienna AKH University Clinic & $121(55.8)$ & $381(62.7)$ & $158(42.5)$ & $209(44.1)$ & & $869(52.0)$ \\
\hline Graz University Clinic & $28(12.9)$ & $94(15.4)$ & $77(20.7)$ & $102(21.5)$ & & $301(18.0)$ \\
\hline Innsbruck University Clinic & $68(31.3)$ & $127(20.9)$ & $92(24.7)$ & $92(19.4)$ & & $379(22.7)$ \\
\hline Linz Elisabethinen Hospital & $0(0.0)$ & $6(1.0)$ & $45(12.1)$ & $71(15.0)$ & & $122(7.3)$ \\
\hline Total, $n$ & 341 & 815 & 430 & 580 & & 2,166 \\
\hline
\end{tabular}

${ }^{a}$ Kendall's T / Kruskal-Wallis.

NW-M Europe = Northwest and Middle Europe; AML = acute myeloid leukaemia; ALL = acute lymphocytic leukemia; MDS = myelodysplastic syndrome; $\mathrm{CML}=$ chronic myeloid leukaemia; $\mathrm{SAA}=$ severe aplastic anaemia. 
Fig. 1. Results of the international donor search in Austria 1988-2010.

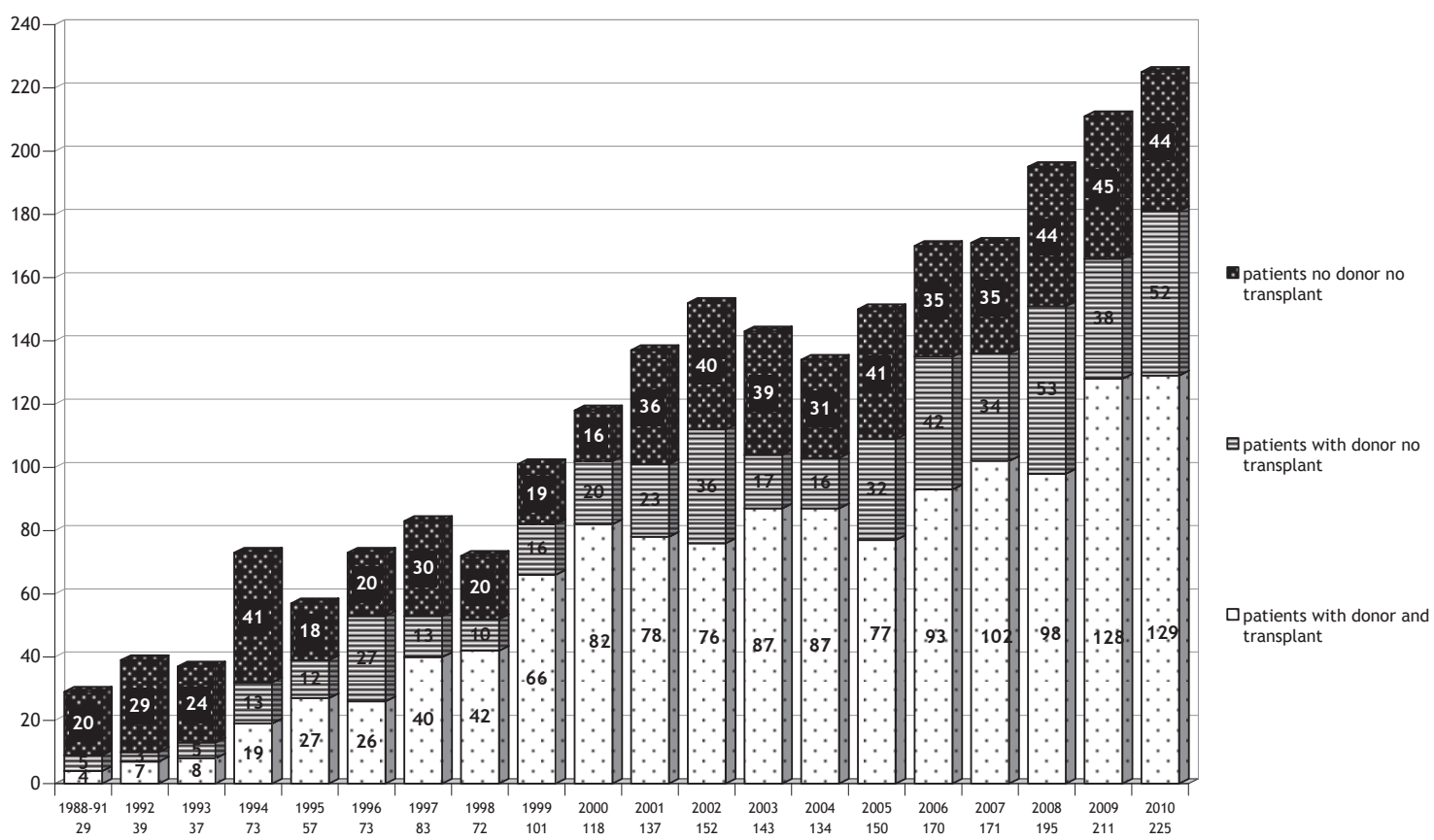

required [14]. Usually, only donors with none or a single HLA mismatch - preferably in HLA-A, -C, or -DQ - were accepted by the transplant physicians. Only in very exceptional cases, donors with 2 HLA mismatches were chosen.

Statistics

Counts, percentages, and medians are provided for basic data description purposes. Kendall's T and Kruskall-Wallis tests were used for the comparison of patient data.

\section{Results}

\section{Patients}

The time frame of our international searches between January 1,1988 and December 31, 2010 spans a period of 23 years. For further analysis, this period has been subdivided into 4: January 1, 1988 to December 31, 1995; January 1, 1996 to December 31, 2003; January 1, 2004 to December 31, 2007; January 1, 2008 to December 31, 2010.

\section{Patient Characteristics}

International donor searches for 495 children and for 1,671 adults, a total of 2,166 patients, were analyzed. Characteristics of the 2,166 patients included in the study can be seen in table 1. The annual number of patients for whom a search was started has generally increased. While the median age of adult patients increased over the years, there was no significant change in the median age of children. More boys than girls were searched for during all periods - also in adults, there were slightly more males than females. In adult patients, the percentage of patients of non-Western or non-Middle European origin rose from 6.9 to $14.8 \%$ from period I to period IV, whereas in children an increase from 18 to $37.7 \%$ was seen. In adults, URD searches for the indications acute myeloid leukaemia (AML), myelodysplastic syndrome (MDS), and lymphoma increased markedly, whereas for chronic myeloid leukaemia (CML) the number of searches decreased substantially. In paediatric patients, a marked decrease in URD searches was recorded for the indications CML, whereas the searches for lymphoma and congenital diseases increased. (table 1).

\section{Overall Results per Year}

In figure 1, data of URD searches and their results are show by year. Generally, it can be seen that the number of patients increased year by year. It can also be seen from figure 1 that during the first years, many patients had no access to a transplant because no donor could be found. After the year 2000, however, a majority of patients could be provided with a matching donor. It is also shown that a certain percentage of patients does not proceed to transplant although a donor is there. In 2010, 181 patients $(80.4 \%)$ found a donor. However, $52(23.1 \%)$ were not transplanted in spite of having a donor. 44 patients $(19.6 \%)$ remained without a donor. Figures are similar for the year 2009: 166 patients $(78.7 \%)$ found a donor, 38 patients (18.0\%) were not transplanted in spite of having a donor, and 45 patients $(21.3 \%)$ remained without a donor.

\section{Overall Results per Period}

In figure 2, the development of the results of the international donor searches in Austria are shown. In the first period of 1988-1995, the results of international donor searches were significantly poorer than in the periods thereafter. In the 3 
Fig. 2. Development of the results of newly initiated international donor searches in Austria.

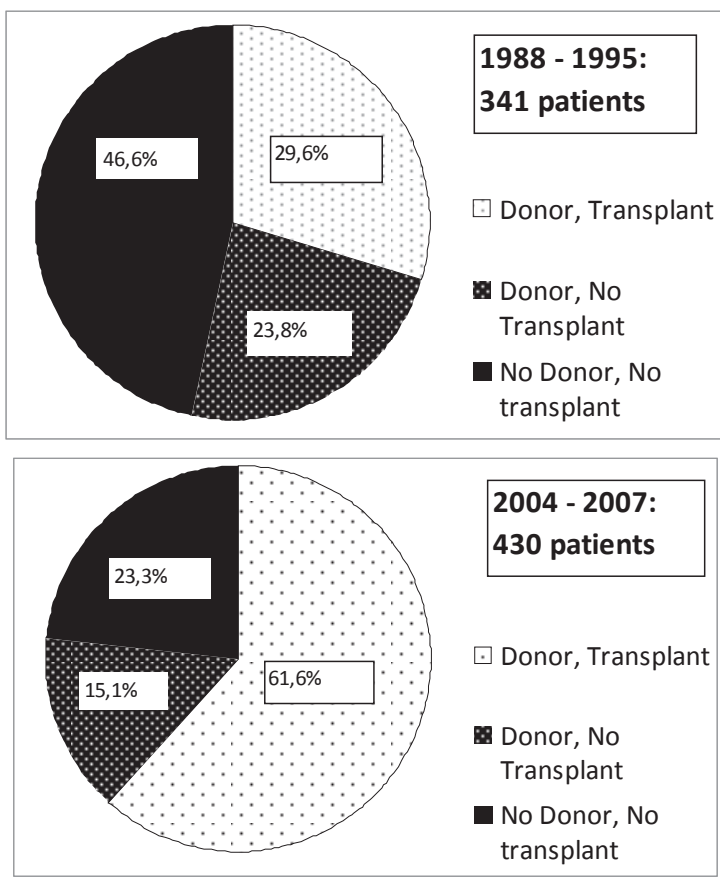

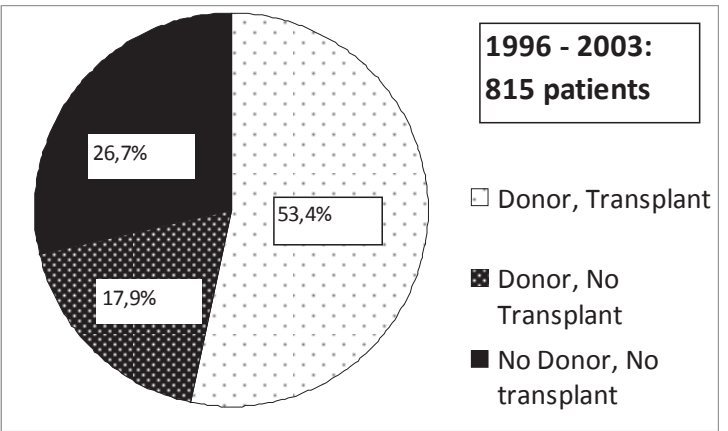

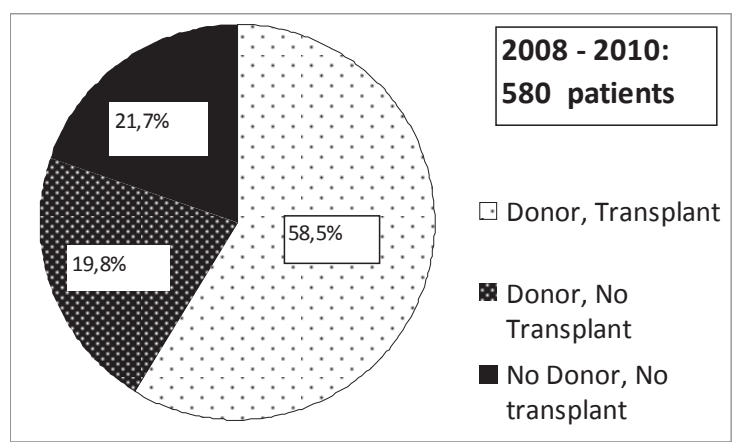

Fig. 3. Transplants from unrelated donors in Austria from 1991 to 2010.

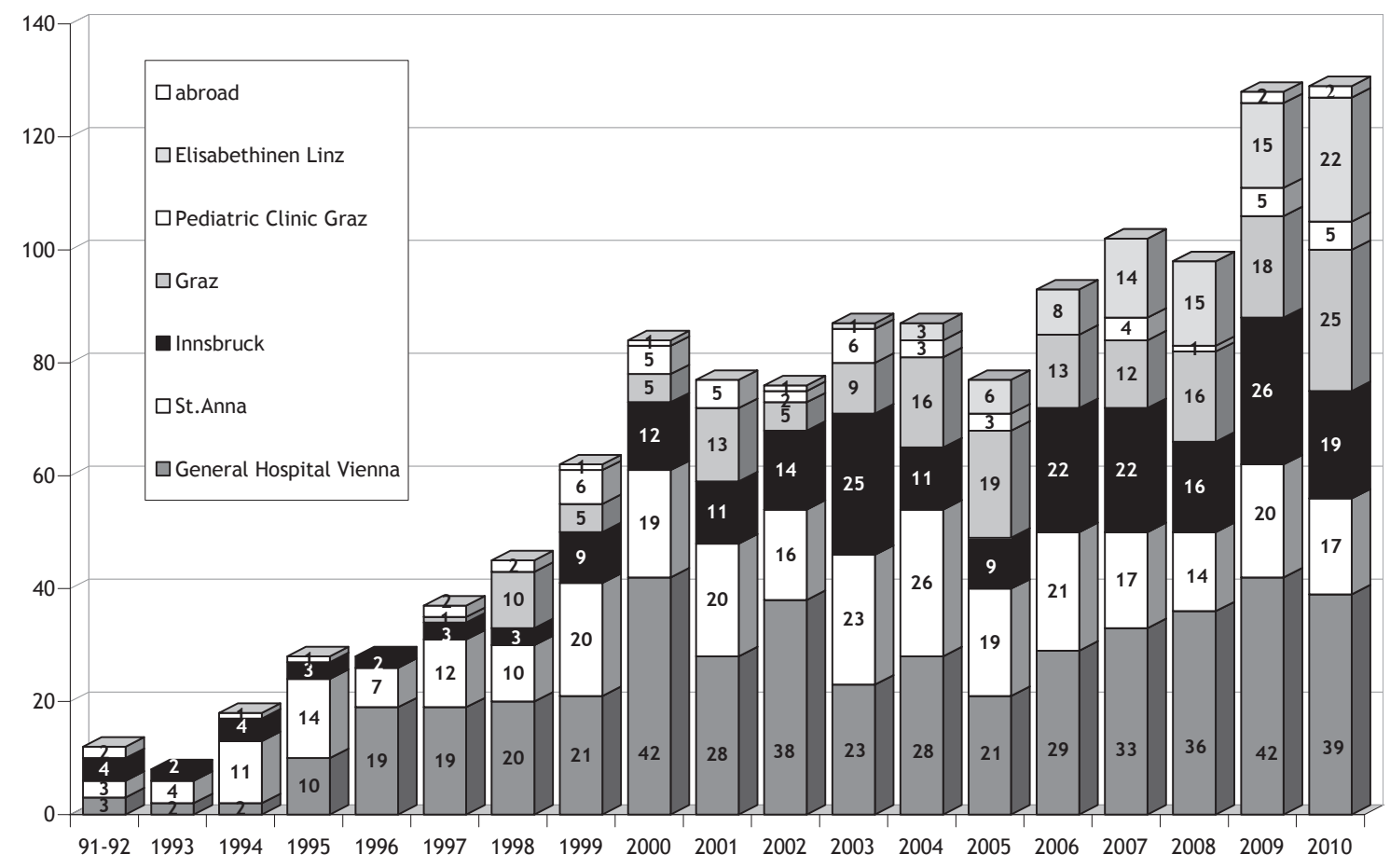

following periods, the percentage of patients who could be provided with a donor and were transplanted was increasing steadily: From $29.6 \%$ in the first period to $53.4,61.6$, and $58.5 \%$ in periods II, II, and IV. It can also be seen from figure 2 , that the percentage of patients for whom no donor could be found is steadily decreasing. The percentage of patients who did not proceed to transplant in spite of having a donor is decreasing only slowly.

\section{Transplants Performed}

Figure 3 shows the numbers of transplants from URD donors performed in Austria per year and transplant centre. Transplants with URD donors are regularly performed in 4 transplant centres for adults and 2 transplant centres for children; 1 transplant centre for children has just started its transplant activities. 
Fig. 4. Country of origin of donations to Austrian patients 1991-2010.
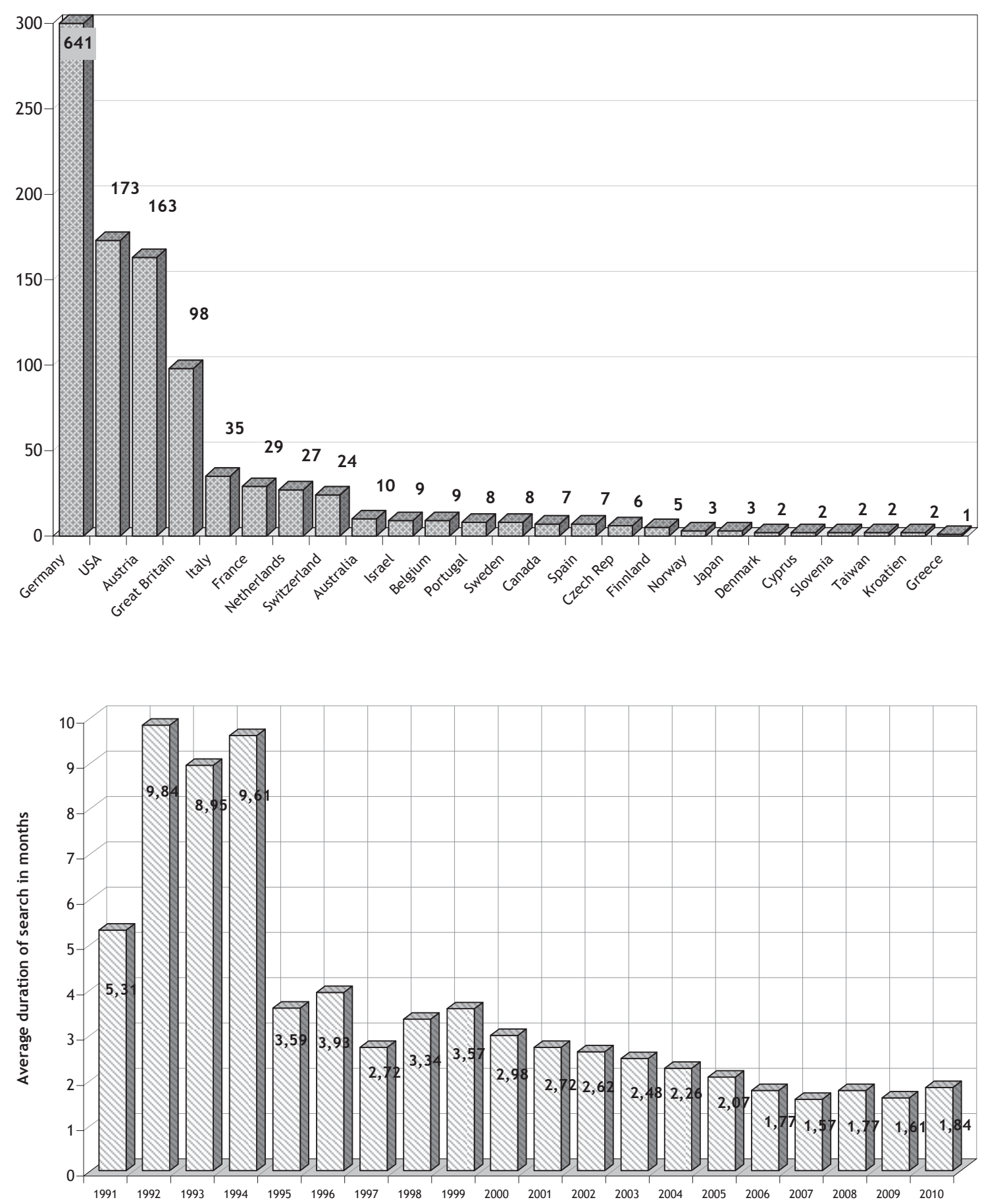

Fig. 5. Duration of international donor searches between 1991 and 2010.

\section{Search Duration}

In the first years of donor search, searches took many months before a matching donor could be identified. In recent years, however, the average duration of an international donor search is between 1.6 and 1.8 months (fig. 5).

\section{Quality of Donations}

In 2010, 66.7\% of the Austrian patients received peripheral blood stem cells (PBSCs), 18.6\% bone marrow, 10.1\% cord blood, and $4.6 \%$ a donor lymphocyte donation. 


\section{Discussion}

In the present study, we show the availability of donors for Austrian patients in need of an unrelated donor. In 2010, for instance, $181 / 225$ patients $(80.5 \%)$ could be provided with a donor. However, 52 (23.1\%) were not transplanted in spite of having a donor. 44 patients $(19.6 \%)$ remained without a donor. Numbers are similar for the year 2009: 166/211 patients (78.7\%) found a donor, 38 patients $(18.0 \%)$ were not transplanted in spite of having a donor, and 45 patients $(21.3 \%)$ remained without a donor (fig. 1). The overall figures of the last period analysed (2008-2010) are very similar: For 78.3\% patients a donor could be found. $22.6 \%$ of the patients could not be transplanted although a donor was identified, and $21.7 \%$ of the patients were unable to find a donor. Nowadays, about $70 \%$ of patients receive PBSCs.

The data reported show that a small country like Austria is very strongly dependent on large international registries providing the local patients with donors. As shown in figure 4, it is the few large international registries that deliver our patients with the majority of donors. If Austria did not have international connections and was dependent only on national donors, only $12.8 \%$ of our patients would be provided with a matching donor.

One of the major problems is that we cannot provide every patient with a compatible donor. For only about $80 \%$ of the patients a donor can be found. Similar data have been reported from other countries. For instance, Heemskerk et al. [15] reported that during the last years, an unrelated donor could be found for $84 \%$ of a patient population that was mainly Dutch. However, only for $59 \%$ of patients of nonNorthwest European descent, the Dutch group was able to find suitable donors.

Unfortunately, not all patients with an identified donor have been transplanted. Between 2008 and 2010, 58.5\% of patients received a transplant. This means that in spite of the availability of a matching donor, $19.8 \%$ of patients did not receive a transplant. The data is also comparable with that of the Dutch study [15] which found that a significant percentage of patients is not transplanted in spite of the presence of a matching donor.

Between 2008 and 2010, 21.7\% of patients did not have a matching donor. Our interpretation of these data is that in these patients, specific combinations of rare HLA determinants occur, making their HLA phenotypes almost unique. Several analyses performed recently by Tiercy et al. [16, 17] have shown that certain rare combinations of rare HLA determinants often occur in patients for whom it is difficult or impossible to identify a matching donor. When the search for a matched URD fails, other options remain for a patient: a related transplant with a haploidentical donor or a transplant with unrelated cord blood. Both are, however, more risky than a transplant from a suitable matched URD [1, 18]. Both options should be offered to the transplant physician as soon as it becomes evident that the patient has only a low chance of finding a completely matching donor.

In conclusion, a patient's chances of finding a suitable URD was $80.5 \%$ in 2010 . Since nowadays the search time has become very short, the matching donor is found within 1.6-1.8 months (within 6 weeks). In 2010, 23.1\% of the patients with a matching donor did not proceed to transplant. In our opinion, it would be desirable that every patient for whom a donor could be identified can also be transplanted. Only one seventh of Austrian patients receive a donation from an Austrian donor. This is due to the fact that the small Austrian registry needs the assistance of the large registries from big countries to provide its patients with matching donors. The Austrian Bone Marrow Donor Registry has round 60,000 donors, 163 of them have, since 1988, donated to Austrian patients, 197 to patients abroad. There are efforts to increase the number of Austrian donors; this is, however, a challenge in a small country with limited resources. Another challenge for national registries - like the Austrian registry - will be the integration of allogeneic cord blood banks and other tissue banks offering advanced cellular therapies. Finding donors from all over the world for Austrian patients is made possible by the outstanding international cooperation between national registries within the framework of the World Marrow Donor Association (WMDA) [19, 20]. Without this cooperation, finding URDs would not be possible for the majority of Austrian patients. In addition, finding suitable donors for Austrian patients would also be impossible without 2 revolutionary international computer systems, BMDW and EMDIS, that identify possible matching donors within seconds and facilitate international cooperation [21, 22].

\section{Acknowledgements}

This paper has been supported by the Jubiläumsfonds der Österreichischen Nationalbank, Project Nr. 6658 and by the Austrian Ministry of Health.

\section{Disclosure Statement}

The authors declared no conflict of interest. 


\section{References}

1 Rowe JM, Goldstone AH: How I treat lymphocytic leukemia in adults. Blood 2007;110:2268-2275.

2 Goldman JM: How I treat chronic myeloid leukemia in the imatinib era. Blood 2007;110:2828-2837.

3 Petersdorf W: The World Marrow Donor Association: 20 years of international collaboration for the support of unrelated donor and cord blood hematopoietic cell transplantation. Bone Marrow Transplant 2010;45:807-810.

4 Foeken M, Green A, Hurley CK, Marry E, Wiegand $\mathrm{T}$, Oudshoorn $\mathrm{M}$; on behalf of the Donor Registries Working Group of the World Marrow Donor Association (WMDA): Monitoring the international use of unrelated donors for transplantation: the WMDA annual. Bone Marrow Transplant 2010;45:811-818.

5 Dahlke J, Kröger N, Zabelina T, Ayuk F, Fehse N, Wolschke C, et al.: Comparable results in patients with acute lymphoblastic leukemia after related and unrelated stem cell transplantation. Bone Marrow Transplant 2006;37:155-163.

6 Kiehl MG, Kraut L, Schwerdtfeger R, Hertenstein B, Remberger M, Kroeger N, et al: Outcome of allogeneic hematopoietic stem-cell transplantation in adult patients with acute lymphoblastic leukemia: no difference in related compared with unrelated transplant in first complete remission. J Clin Oncol 2004;22:2816-2825.

7 Weisdorf DJ, Anasetti C, Antin JH, Kollman C, Snyder D, Petersdorf E, et al: Allogeneic bone marrow transplantation for chronic myelogenous leukaemia: comparative analysis of unrelated versus matched sibling donor transplantation. Blood 2002;99:1971-1977.

$>8$ Moore J, Nivison-Smith I, Goh K, Ma D, Bradstock K, Szer J, et al: Equivalent survival for sibling and unrelated donor allogeneic stem cell transplantation for acute myelogenous leukaemia. Biol Blood Marrow Transplant 2007;13:601-607.
9 Yakoub-Agha I, Mesnil F, Kuentz M, Boiron JM, Ifrah N, Milpied N, et al: Allogeneic marrow stem-cell transplantation from human leukocyte antigen-identical siblings versus human leukocyte antigen-allelic-matched unrelated donors (10/10) in patients with standard-risk hematologic malignancy: a prospective study from the French Society of Bone Marrow Transplantation and Cell Therapy. J Clin Oncol 2006;36:5695-5702.

10 Bochtler W, Maiers M, Bakker JN, Oudshoorn M, Marsh SG, Baier D, Hurley CK, Müller CR: World Marrow Donor Association framework for the implementation of HLA matching programs in hematopoietic stem cell donor registries and cord blood banks. Bone Marrow Transplant 2011; 46:338-343.

11 Maiers M, Bakker A, Bochtler W, Eberhard H-P, Marsh SGE, Müller C, Rist H-G; on behalf of the Information Technology Working Group (ITWG) of the WMDA: Information technology and the role of WMDA in promoting standards for international exchange of hematopoietic stem cell donors and products. J N Bone Marrow Transplant 2010;45:839-842.

12 Van Rood JJ, Oudshoorn M: Eleven million donors in Bone Marrow Donors Worldwide! Time for reassessment? Bone Marrow Transplant 2008;41:1-9.

13 Statistik Austria (ed): Volkszählung 2001, Textband. Die demographische, soziale und wirtschaftliche Struktur der österreichischen Bevölkerung. Vienna, Statistik Austria, 2007.

14 Hurley CK, Maiers M, Marsh SGE, Oudshoorn M: Overview of registries, HLA typing and diversity, and search algorithms. Tissue Antigens 2007;69:3-5.
15 Heemskerk MBA, van Walraven SM, Cornelissen JJ, Barge RMY, Bredius RGM, Egeler RM, et al.: How to improve the search for an unrelated haematopoietic stem cell donor. Faster is better than more! Bone Marow Transplant 2005;35:645652.

16 Tiercy J-M, Passweg J, A van Biezen, Zander A, Kröger N, Gratwohl A, et al: Isolated HLA-C mismatches in unrelated donor transplantation for CML. Bone Marrow Transplant 2004;34:249-255.

17 Tiercy J-M, Nicoloso G, Passweg J, Schanz U, Seger R, Chalandon Y, et al: The probability of identifying a 10/10 HLA allele-matched unrelated donor is highly predictable. Bone Marrow Transplant 2007;40:515-522.

18 Burke MJ, Vogel RI, Janardan SK, Brunstein C, Smith AR, Miller JS, Weisdorf D, Wagner JE, Verneris MR: Early lymphocyte recovery and outcomes after umbilical cord blood transplantation (UCBT) for hematologic malignancies. Biol Blood Marrow Transplant 2011;17:831-840.

19 Goldman JM: Special report: bone marrow transplants using volunteer donors - recommendations and requirements for a standardized practice throughout the world - 1994 update. Blood 1994;84: 2833-2839.

20 Hurley C, Raffoux C: Special report: World Marrow Donor Association: international standards for unrelated haematopoietic stem cell registries. Bone Marrow Transplant 2004;34:103-110.

21 Baouz A, Raffoux C: EMDIS: European Marrow Donor Information System. Comput Methods Programs Biomed 1994;45:45-46.

22 Müller $\mathrm{CH}$ : Computer applications in the search for unrelated stem cell donors. Transpl Immunol 2002;10:227-240. 